\title{
Information technology in the penitentiary crimes prevention and specific environmental crimes investigation
}

\author{
Dmitry Grishin ${ }^{1}$, Andrey Nuzhdin ${ }^{1, *}$, Talat Suleymanov ${ }^{1}$, and Vera Yakovleva ${ }^{1}$ \\ ${ }^{1}$ Academy of the Federal penitentiary service of Russian Federation, 1 Sennaya str., Ryazan, 390000, \\ Russian Federation
}

\begin{abstract}
In recent years, there has been a tendency in the digitalization of all spheres of public life, the introduction of information technology and the use of technical means. At scientific events of various levels, they discuss the importance, necessity and possibility of using certain achievements of information technology. In Russia and other countries of the world, exhibitions of technical means, security means are annually held (Sfitex, Securexpo, Interpolitech, etc.) where one can witness achievements in this area. Naturally, the results of technological advances began to be actively used in the activities of law enforcement agencies, including the prevention of penitentiary crimes. This article is devoted to the study of use of information technology and technical means in the prevention of penitentiary crimes. This issue has more than once become the object of discussion of scientists and practitioners. Based on the analysis of doctrinal sources, scientific research, statistical data, the article formulates a theoretical substantiation of the importance, necessity and effectiveness of use of information technologies and technical means in the prevention of penitentiary crimes.
\end{abstract}

\section{Introduction}

Modern society is constantly undergoing changes in this or that area of life. Technological and informational changes have affected all spheres of public life: be it simple communication or crime prevention. We can safely say that we are at the origins of a revolution that will fundamentally change life, work and communication. We are witnessing massive changes across all branches of science and technology. As for the social sphere, a paradigm shift is taking place in the way we work and communicate, express ourselves, receive and transmit information. A similar transformation is taking place at the level of governments and state institutions, as well as, along with other systems, in education, health care, public order, crime prevention.

Almost all states of the world are flexible enough to react to the ongoing changes. In order to solve current problems and prevent possible problems of widespread digitalization, developed countries adopt strategic action documents (in Germany - "Industry 4.0", in

${ }^{*}$ Corresponding author: andrey78@yandex.ru 
China - "Internet +", in the USA - "Industrial Internet Consortium", in Japan - "Society 5.0" , in Russia - "Digital Economy of Russian Federation"). In one form or another, one of the directions of each of the named projects is to provide conditions for successful implementation and use of information technologies.

At present, the information space in all spheres of life is being actively formed in Russia. Gradual, planned, controlled and logical development presupposes the widespread introduction of a whole range of technologies: analysis of large amounts of data, use of "artificial intelligence", modern production technologies, wireless communications, virtual and augmented reality.

Relatively recently, Russia approved the Strategy for Development of Information Society (Decree of President of Russian Federation of May 9, 2017 No. 203. Collected Legislation of Russian Federation, No. 20, 05/15/2017, Article 2901), which defines the goals, objectives and measures for implementation of internal and foreign policy of Russian Federation in the field of application of information and communication technologies, aimed at the development of information society, formation of a national digital economy, ensuring national interests and implementing national priorities. This document assumes legislative consolidation of introduction of information technologies and possibility of their widespread use.

Representatives of scientific community, specialists in the field of law subtly react to the ongoing changes, closely monitor (and actively participate) in the scientific understanding and practical use of information technologies in a particular area. The activities of various officials on the crime prevention, including unlawful acts committed in the institutions of penal system, did not go unnoticed.

The purpose of the study is to scientifically understand the practical use of information technology in the prevention of penitentiary crimes by various officials: interrogators, investigators, employees of penal system.

To achieve this goal, it is necessary to fulfill a set of following tasks:

- to determine the essence of information technologies used in the prevention of penitentiary crimes;

- to evaluate the effectiveness of use of various technical means to prevent commission of penitentiary crimes;

- to consider the use of information technology in organizing the investigation of penitentiary crimes;

- to designate the information security of identifying and eliminating the circumstances that contributed to the commission of penitentiary crimes.

\section{Methods}

The issues of digitalization and use of information technologies in criminology, forensic science and criminal procedure were actively developed by A.V. Sukhodolov, S.V. Ivantsov, T.V. Molchanova, B.A. Spasennikov and M.A. Kalukhina, Golovko L.V., Grigoriev V.N., Zuev S.V., Nikitin E.V., Alexandrov A.S., Kachalova O.V., Tsvetkov Yu.A.. A.V. Serebrennikova pointed to a new level of tasks in combating crimes committed using information technologies. D.A. Grishin pointed out the issues of digitalization of pretrial criminal proceedings, the use of information technologies in the course of investigation of crimes. Ethical and axiological aspects of digitalization of criminal procedural activity were raised in the works of A.V. Pobedkin. Aspects of prevention of certain types of penitentiary crimes using information technologies and technical means were considered in the works of A.A. Nuzhdin. Information technologies (in particular, computer programs) have already been used in the establishment of guilt and appointment of criminal penalties. In addition to the above mentioned works and directions of scientific research, scientific 
literature contains other studies of different years concerning the use of information technologies in the process of disclosing, investigating and preventing crimes. Nevertheless, despite the vast geography and diversity of scientific works, the issues of using information technologies in the prevention of penitentiary crimes (moreover, in such a broad aspect) have not been fully investigated.

In the process of preparing this article, various general scientific and private scientific methods of cognition were consistently applied.

At the initial stage of this scientific research, when considering individual information technologies and their use at different stages of preventive activity, there were universal methods of cognition: analysis and synthesis. In the process of highlighting the individual properties of information technologies, with the simultaneous determination of objects of interest, the abstraction method was used.

At the next stage of scientific research, when considering various points of view of scientists, a formal-logical method was used; in the process of analyzing the practice of using information technologies, various empirical methods were used.

At the final stage, when considering the possibility of using information technologies in the framework of criminal procedural, criminological and forensic activities, dialectical method of scientific knowledge was used.

When describing the results of this scientific study, method of generalization with elements of incomplete deduction was mainly used.

\section{Results}

The study shows that the use of information technologies in the course of indicated areas of fighting crime will increase the efficiency of this activity, reliably ensure compliance with various procedural requirements, and make this process more accessible and objective. The authors came to the conclusion that the direction of use of certain information technologies and technical means in the fight against crime is different and depends on the level at which this implementation is carried out - prevention of commission of crimes, investigation of crimes committed. It should be borne in mind that success of the use of information technology and technical means in the prevention of penitentiary crime and investigation of specific crimes depends on the intensity and consistency of interaction between law enforcement agencies of different departmental affiliation.

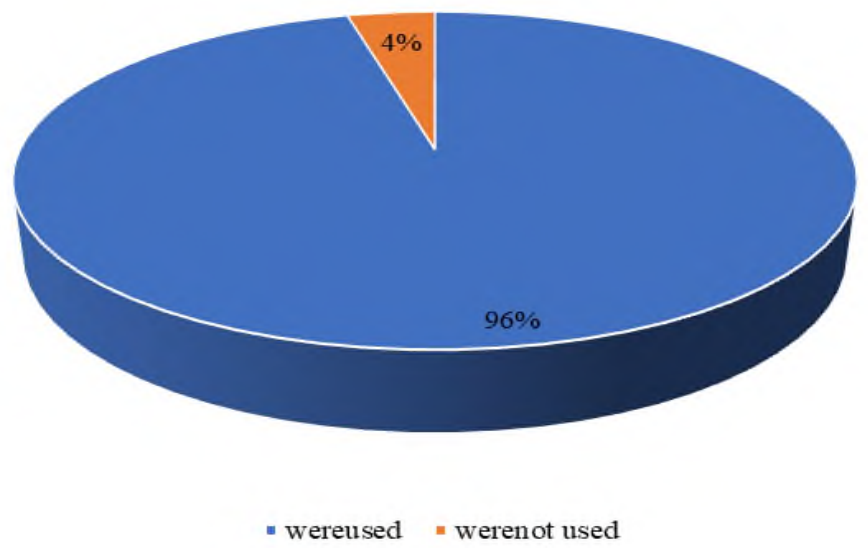

Fig. 1. The use of information technology and technical means in the prevention of penitentiary crimes (based on the materials of criminal cases). 


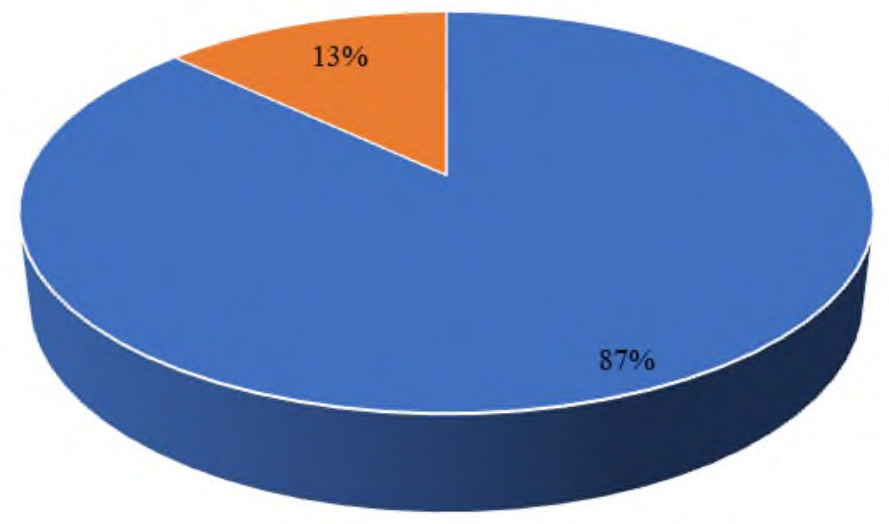

- wereused " werenot used

Fig. 2. The use of information technologies in the investigation of penitentiary crimes (based on the materials of criminal cases).

\section{Discussion}

Ensuring the prevention of crimes committed in the institutions of penal system involves use of modern information technologies. Their use contributes to successful preventive activity, regardless of means, techniques and methods used. Information technologies are successfully used both in the process of identifying intent to commit a penitentiary crime, disclosing a criminal act, identifying circumstances that contributed to the commission of crimes, organizing the investigation process. The circle of persons who use information technologies for the prevention of penitentiary crimes is also quite wide: an interrogator, an investigator, a specialist, an expert, an employee of penal system.

Organization of supervision over convicts and persons in custody, admission to the territory of institution of penal system, examination and search of people, vehicles and objects, production of investigative, operational-search and security actions - organization of prevention, disclosure and investigation of crimes for a long period of time passes using both traditional means and information technology.

Unfortunately, there are cases when persons in institutions of penal system commit crimes, and their number is steadily growing (Table 1).

Table 1. Quantitative characteristics of penitentiary crimes.

\begin{tabular}{|c|c|c|c|}
\hline Year & $\begin{array}{c}\text { Number of convicted persons } \\
\text { and persons in custody }\end{array}$ & $\begin{array}{c}\text { Number of registered } \\
\text { penitentiary crimes }\end{array}$ & $\begin{array}{c}\text { Crime rate } \\
\text { for 1000 people }\end{array}$ \\
\hline 2015 & 646085 & 940 & 1.45 \\
\hline 2016 & 630155 & 960 & 1.52 \\
\hline 2017 & 602176 & 977 & 1.62 \\
\hline 2018 & 574447 & 1024 & 1.78 \\
\hline 2019 & 535514 & 1171 & 2.18 \\
\hline 2020 & 495841 & 1181 & 2.38 \\
\hline
\end{tabular}


It can be concluded that prevention of penitentiary crimes is an important (if not the main) task of activities of both employees of penal system and employees of other law enforcement agencies.

The prevention of penitentiary crimes can be conditionally divided into activities to identify the causes and conditions that contribute to the commission of crimes and activities to eliminate previously identified causes and conditions.

Information technologies and technical means can be classified according to the direction of their use in the prevention of penitentiary crimes:

1. Technologies and means creating conditions that make it difficult or impossible to commit a crime. Often, such conditions are achieved by the generalization of results of forensic examinations, practice of investigating penitentiary crimes, implementation of results of recommendations of experts and specialists. In this context, the use of information technology and various technical means should be aimed, for example, at eliminating defects found in locking devices; complicating or making it impossible to open a door, window; technical means of detecting prohibited items, etc.

With regard to the activities of penitentiary system, such means include complexes of video surveillance and detection systems: integrated security systems used to supervise persons held in penitentiary institutions; access control systems; sets of television video surveillance systems; CCTV Cameras.

2. Use of various forensic and other accounts, departmental statistical reporting data developed and used in the penal system. Systematic accounting of certain objects for the subsequent use of accounting and registration data in the process of disclosing, investigating and preventing crimes using the achievements of information technology will contribute to better storage and faster search of the data of interest. Unfortunately, currently there are a number of problems in the penitentiary system that have not been resolved:

- the general problem of organizing information support for the activities of penal system - a large number of indicators required for the report. It is necessary to determine the minimum acceptable, but sufficient number of benchmarks. It is necessary to determine those flows of information that are needed at the present moment to achieve a specific goal (for example, predicting crime);

- an unjustifiably overestimated number of statistical reporting forms, which often does not allow comparison, analysis of data from various structural units of penal system or areas of activity;

- the volume of information transmitted within the framework of statistical reporting is growing from year to year. This situation can (and often does) lead to a loss of operational control of penal system, hinders rapid decision-making in the field of prevention of penitentiary crimes;

- the absence of scientifically grounded objective criteria for assessing the results of activity of penal system, some criteria are no longer relevant at the moment; duplication of information in various forms of statistical reporting; diversity of data characterizing the same phenomena, but presented in different forms of statistical reporting; the use of different formulations of the same phenomena, processes, objects in different forms of statistical reporting; use of various sources of primary data (different forms of statistical reporting) and various methods of analysis and information processing;

- an imperfection, and sometimes an excess (taking into account the development of information technologies) of systems for analysis and processing of databases.

3. Information technologies and means of prevention of prepared and suppression of begun penitentiary crimes. Assessing the role of various information technologies and means in the prevention and suppression of penitentiary criminal activity, it is necessary to proceed from both the preventive value of traditional forensic techniques and special devices (developed using information technologies) designed to prevent and suppress 
criminal activity. The use of the above mentioned types of technical means contributes to the prompt detection of crimes, which has an important general preventive value. The preventive value of special technical means intended for the prevention and suppression of penitentiary crimes lies in the fact that with their help it is possible to interrupt a crime that has begun and to exclude the onset of socially dangerous consequences. Thus, the use of various signaling systems (radio wave burglar alarms, integrated security systems) makes it possible to suppress escape of convicts and persons in custody through the main fence. Systems and readers of biometric personality indicators help prevent unauthorized persons from entering the restricted area. Passive and active metal detectors, technical means of detecting and fighting unmanned aerial vehicles, detectors of nonlinear transitions, X-ray installations allow to prevent the penetration of various prohibited items (weapons, ammunition, drugs, mobile phones into the territory of a correctional institution or pre-trial detention center).

Fulfilling of the tasks of criminal proceedings is currently not possible exclusively through the classical methods of searching, fixing, researching and evaluating information regarding the crime event that has occurred, using traditional methods and means of organizing criminal procedural activities. In this regard, it is necessary to create an appropriate information space that allows the use of necessary resources for the needs of criminal proceedings.

The current legal framework for criminal procedural activity opens up wide opportunities for implementation of various information resources in the course of pre-trial proceedings in a criminal case.

Following classification of information technologies in the field of criminal justice seems to be possible:

1. Communicative information technologies.

2. Information technologies that guarantee the legal status of powerless participants in criminal proceedings.

3. Information technologies for storing evidential information.

We tend to propose following ways to improve criminal justice through more intensive use of information technology:

1. Conducting an electronic criminal case.

2. Updating the process of using automated workstations.

3. Improvement of the procedure for production of individual investigative actions through the use of technical means of recording their progress and results.

Conducting a criminal case in digital form will optimize the work of an investigator, an interrogator by reducing the time spent on the procedural registration of actions and decisions taken, ensure remote interaction between law enforcement agencies, guarantee the legal status of an individual, increase the legality of relevant activities, including through prosecutorial supervision departmental and judicial control.

To conduct electronic criminal proceedings, it is necessary to have an appropriate software shell, which will allow placing the materials of criminal cases in production, with the possibility of replenishing them online in the event of new procedural actions. At the same time, a specified system should provide for level access of interested parties to familiarize themselves with the materials, to exercise control and supervisory functions, to ensure interaction between various bodies of preliminary investigation.

It seems expedient to coordinate the electronic investigation system with the available information resources of judicial authorities. So it should be considered positive to introduce a procedure for sending for consideration the petitions of investigators, the inquiry officer, requiring judicial authorization.

Conducting an electronic investigation requires the use of appropriate technical means by investigators, interrogators, and their leaders. This problem can be solved through the 
use of automated workstations, which should be considered as information technology, including:

1. information technology of data processing;

2. information retrieval and information and reference technologies;

3. information technology decision support.

\section{Conclusion}

Based on the above mentioned, it can be argued that the use of information technologies and technical means in the prevention of penitentiary crimes is carried out in the following directions:

- identification of criminally important information about the circumstances that contributed to the commission of penitentiary crimes;

- analysis of committed penitentiary crimes and subsequent development of scientific and technological measures that complicate, or make it impossible to commit a penitentiary crime;

- use of information technology and technical means in the prevention and suppression of penitentiary crimes.

The intensification of work on the use of information technologies and technical means in the activities of penitentiary system will contribute to the prevention of penitentiary crimes and their disclosure and investigation.

\section{Acknowledgments}

The authors express their deep gratitude to the management of the Ugra State University and the Academy of the Federal Penitentiary Service of Russia for the help and support provided in the course of this study.

\section{References}

1. Dae-Young Kim, SAGE Open 4(3) (2014) DOI 10.1177/2158244014542086

2. K. Schwab, The fourth industrial revolution (Eksmo, 2016)

3. E.A. Russkevich, State and law 7, 77-84 (2020)

4. A.P. Sukhodolov, S.V. Ivantsov, T.V. Molchanova, B.A. Spasennikov, M.A. Kaluzhin, All-Russian criminological journal 12(2), 230-236 (2018) DOI: 10.17150 / 25004255.2018.12 (2). 230-236

5. L.V. Golovko, Bulletin of economic security 1, 15-25 (2019)

6. V.N. Grigoriev, Modern criminal procedural law - lessons of history and problems of further reform 1.1(1), 143-151 (2019)

7. S.V. Zuev, E.V. Nikitin, All-Russian criminological journal 11(3), 587-595 (2017)

8. A.S. Alexandrov, Judicial power and criminal procedure 2, 130-139 (2018)

9. O.V. Kachalova, Yu.A. Tsvetkov, Russian Justice 2, 95-101 (2015)

10. A.V. Serebrennikova, All-Russian criminological journal 14(3), 423-430 (2020)

11. D.A. Grishin, Bulletin of Tomsk State University 455, 208-215 (2020)

12. A.V. Pobedkin, Bulletin of Moscow University of the Ministry of Internal Affairs of Russia 3, 50-55 (2020)

13. A.A. Nuzhdin, Bulletin of the penal system 8(219), 35-43 (2020) 
14. V.F. Lapshin, Penitentiary science 14(2), 192-198 (2020)

15. A. Adriaenssen, L. Paoli, S. Karstedt, J. Visschers, V.A. Greenfield, S. Pleysier, European Journal of Criminology 17(2), 127-150 (2020)

16. V.F. Lapshin, S.A. Korneev, R.V. Kilimbaev, IOP Conference Series: Materials Science and Engineering 1001, 012144 (2020) DOI: 10.1088/1757899X/1001/1/012144

17. M.S. Gusarova, A.V. Kopytova, I.G. Reshetnikova, Periodico Tche Quimica 16(31), 903-912 (2019)

18. Y. Truntsevsky, V. Lez'er, S. Belyasov, A. Kopytova, E3S Web of Conferences 157, 03016 (2020) 